\title{
Promoting Children's Healthy Social-Emotional Growth: Dialogue Journal
}

\author{
Chiaki Konishi ${ }^{1} \&$ Sol Park ${ }^{2}$ \\ ${ }^{1}$ Department of Educational and Counselling Psychology, McGill University, Montreal, Canada \\ ${ }^{2}$ Department of Psychology, McGill University, Montreal, Canada \\ Correspondence: Chiaki Konishi, Department of Educational and Counselling Psychology, McGill University, \\ 3700 McTavish Street, Montreal, QC, H3A 1Y2, Canada. E-mail: chiaki.konishi@mcgill.ca
}

Received: December 9, 2016

Accepted: January 20, 2017

Online Published: February 13, 2017

doi:10.5539/jel.v6n2p246

URL: http://doi.org/10.5539/jel.v6n2p246

\begin{abstract}
Dialogue journals are a form of writing in which a student and a teacher carry on a conversation over time. This paper addresses the benefits of using dialogue journals for promoting a positive social-emotional learning (SEL) environment for children in school settings. Educators and researchers have increasingly acknowledged the importance of SEL in schools, and the recognition has been gradually spread around the world in recent years. Despite the increased recognition of the importance of SEL, teachers often appear to feel unacquainted with tactics for promoting children's social-emotional growth. We provide our readers with a theoretical and practical rationale behind the benefits in the framework of SEL. We also provide practical guidelines for the implementation of the dialogue journals in schools. Further, successful examples of the use of dialogue journals which we have drawn upon during classes in different countries are presented in order to help teachers promote the positive SEL environment for students at school.
\end{abstract}

Keywords: dialogue journal, social-emotional development, school climate, student-teacher rapport, collaborative learning

\section{Introduction}

We have known for a long time that an aspect of social and emotional learning is important to enhance children's well-being. For instance, Ashdown and Bernard (2012) looked at the effects of implementing a social and emotional learning skills program called the You Can Do It! Early Childhood Education Program (YCDI) on 99 grade 1 students. The results supported the importance of social and emotional learning in strengthening children's well-being - children who received YCDI had increased levels of social-emotional competence, they managed their emotions more effectively and were able to get along with their peers better than those who did not receive the program. The study also found a decrease in problem behaviours and greater reading achievement levels in students who completed the program.

Furthermore, research (Brackett, Elbertson, \& Rivers, 2015) has suggested that children who have developed their emotional skills tend to have an increased level of social competence, good mental health and good academic performance compared to those children who have not adequately developed their emotional skills. These latter children are reported to have poorer mental health than the former children, including experiencing depression and anxiety. They also engage in more destructive relationships as well as being associated with drugs and alcohol (Brackett et al., 2015).

However, social and emotional learning (SEL) is still neglected, because of traditional emphasis or pressure from academic reliance on the three "R's" of reading, writing, and arithmetic in our education system (Greenberg et al., 2003; Jaffe, Wolfe, Crooks, Hughes, \& Baker, 2004; Schonert-Reichl \& Hymel, 1996). Components of social-emotional development including Autonomy, Belonging, and Competence (Ryan \& Deci, 2000; Ryan \& Powelson, 1991) are critically associated with academic and life success. We are still continuing to understand the importance of this area.

The purpose of this paper is to propose the benefits of using dialogue journals at school to foster a positive SEL environment for students at school. This paper provides the audience not only with theoretical and practical rationale behind the benefits of dialogue journal use but also with practical guidelines for the implementation of 
the dialogue journals. In addition, successful examples of the use of dialogue journals which we have drawn upon during classes in different countries will be presented in order to help teachers promote the positive SEL environment for students at school.

\subsection{Social and Emotional Learning}

Social and emotional learning (SEL) is defined as the process through which children develop their ability to integrate thinking, feeling, and behaving, to achieve important life tasks (Zins, Bloodworth, Weissberg, \& Walberg, 2004). Individuals competent in SEL are expected to be able to recognize and manage their emotions, establish healthy relationships, set positive goals, meet personal and social needs, and make responsible and ethical decisions (Payton et al., 2000). As educators, we are in general agreement that it is important for schools to foster children's social-emotional development in a way that it has an impact on non-academic outcomes such as children's physical and psychological health, for example, reduction of violence and substance use (e.g., McWhirter, McWhirter, McWhirter, \& McWhirter, 2003; Payton et al., 2000). However, recent research has shown that SEL plays a critical role in impacting academic functioning and life success as well (Christenson \& Havsy, 2004; Durlak, Domitrovich, Weissberg, \& Gullotta, 2015; Durlak, Weissberg, Dymnicki, Taylor, \& Schellinger, 2011; Farmer, Lines, \& Hamm, 2011; Mlecki \& Elliott, 2002; Pianta \& Hamre, 2009; Schonert-Reichl \& Hymel, 1996; Wentzel, 1993).

As previously described, key components for SEL growth include autonomy, belonging, and competence (Ryan \& Powelson, 1991). School success requires students to take initiative and be responsible for their learning (autonomy/ownership), to have interpersonal bonds with school, school staff, and peers (belonging), and to have a sense of mastery (competence). It is important for us to be aware that effective SEL is optimized within caring, supportive, and safe environments. Considering these important elements, schools can provide a unique opportunity for promoting children's social-emotional development. Some children may have a fortunate opportunity to develop social and emotional skills through their experiences with parents, friends, community members and extra-curricular activities. Thus, they are at an advantage compared to those children who do not have these opportunities outside of school in developing social and emotional learning competencies, such as self-awareness, self-management and social awareness, relationship skills and responsible decision making (Elias et al., 2015). Therefore, educators play a tremendous role in providing social and emotional learning to other children who do not have these experiences at home or in their neighbourhoods, and who are at risk of struggling academically and socially. Despite the potentially great opportunities for encouraging social-emotional growth, teachers often appear to feel unacquainted with tactics for promoting children's social-emotional growth.

Let us take an example by looking at a theoretically based approach to social and emotional learning. RULER is an approach that was designed to be used by educators to foster an emotionally intelligent school environment (Brackett et al., 2015). The model of RULER is to emphasize that students will be more "effective" when they can Recognize, Understand, Label, Express, and Regulate their emotions. Early research, however, showed that although RULER was designed for educators to use, students were not developing emotional skills efficiently because some teachers were uncomfortable teaching it, whereas others simply did not want to teach it (Brackett et al., 2015). Thus, the content in which RULER or any other social and emotional learning techniques are delivered is a crucial factor in the development of emotional skills among students.

Subsequently, we introduce how effectively dialogue journals could be one of the most useful tools to help teachers promote the positive SEL environment for students at school.

\subsection{Dialogue Journal}

In order to stimulate efficient SEL in schools, dialogue journal writing can be used to promote this kind of learning. As mentioned above, SEL is a way to promote integrative development of thinking, feeling and behaving, and thus allowing the child to develop an enhanced level of understanding (Zins et al., 2004). The nature of dialogue journals is interactive, as it allows the student to express his or her feelings and thereby, explore emotions with the teacher during the learning process which is crucial to the well-being of the child (Eski, 2013; Fulwiler, 1987; Gambrell, 1985).

Daniels and Daniels (2013) describe the use of a technique that they call "written conversations" which includes the use of dialogue journals. They describe that these "written conversations" allow students to communicate creatively, critically and actively with their peers and teachers all together, instead of one at a time. Daniels and Daniels describe the functioning of "written conversations" in four steps. First, teachers use short letters addressed to individual students to introduce themselves and to make a connection with their students. This 
technique is known as "mini-memos". Second, the method of dialogue journaling is implemented for the teacher and the student to have deep and critical, but also open discussions related to academic subjects. Third, students engage in what Daniels and Daniels describe as "write-arounds," where students are put into small groups and they can write down a response to a video clip, or poem, or story. After a few minutes, the students pass their response to the student next to them and they write a response to the previous student's response, and so on. The students can then discuss verbally about their thoughts and ideas about the video, poem or story. Daniels and Daniels argue that by using "write-arounds," students are more motivated and engaged in participating in discussions with their peers. Finally, students get involved in having discussions online with peers from their classrooms and from around the world.

Dialogue journals could be of great use to create positive school environments to enhance children's social-emotional development for the following key reasons. First, they promote rapport between teachers and students, in which students disclose their concerns (Hail, George, \& Hail, 2013; Staton, Shuy, Kreeft-Peyton, \& Reed, 1988). Second, they enhance collaborative learning between teachers and students (Bruner, 1988). In the following, we discuss these reasons by beginning with the definition of dialogue journals in order to seek the possible application of journal writing to the context of SEL promotion in schools.

\subsection{Building Student-Teacher Rapport}

A strong student-teacher rapport is crucial for the well-being and positive development of a child during school years. A coherent and strong relationship between the student and the teacher allows for a safe and secure environment for the student to explore and develop their academic capabilities, recognize their emotions and establish positive relationships with their peers (Hamre \& Pianta, 2006). For example, Skalicka and colleagues (Skalicka, Stenseng, Belsky, \& Wichstrom, 2015) studied the association between student-teacher relationships and behavioural problems of children in 819 4-year-old children until first grade. They found that greater student-teacher rapport indicated fewer behavioural problems in students in small groups compared to poor student-teacher relationships.

Dialogue journals are a form of writing in which a student and a teacher carry on a conversation over time (Staton, 1987). A number of researchers have supported dialogue journals because they provide opportunities to develop mutuality between student and teacher (e.g., Kreeft-Peyton \& Seyoum, 1989; McGrath, 1992; Potts, 1981; Staton, 1980; Staton et al., 1988; Wall, 1981). Having conducted the in-depth reading of 15 of 26 sixth-grade students' journals available, Staton et al. (1988) found that only three or four journals lacked evidence of substantial development of mutual understanding after one school year. In this study, students began writing about "safe topics" such as their problems with homework and other academic areas. However, after a certain period of time, students found their own ways of freely expressing their frustration, feelings, and complaints to their teacher (Staton et al., 1988). Referring to a similar study, Kreeft-Payton and Seyoum (1989) illustrated the process of how the mutuality was built between a student and a teacher.

Students write regularly to the teacher. The teacher writes back, ideally-not to evaluate or correct the writing, but as a co-participant in it. Because the interaction is written and time passes between contributions by the participants both can introduce a number of topics in one journal entry. Topics are introduced, responded to, and dropped as the writers see fit. Where there is mutual interest, a topic can be continued for an extended period of time (p. 311).

Kreeft-Payton (1988a) concluded that equal participation in the process of keeping the journals promoted developing trust and mutual understanding. On this foundation, both students and their teacher can move on to new levels of mutual understanding about more in-depth topics. Accordingly, students start revealing their real concerns in the dialogue journals. This function of the journal has been supported by a number of other scholarly works (e.g., Casanave, 1993; Hall \& Duffy, 1987; Potts, 1981; Staton, 1980).

According to Galarza, a teacher who has been teaching for 33 years, dialogue journals are especially important in the education setting as it promotes getting students to write daily and to build a connection with the teacher. Dialogue journals also encourage students to use "authentic" and "real" language. Furthermore, Galarza describes that complaints and questions arise the most in the dialogue journals she sees from her students, however, students rarely speak up in the regular classroom settings to talk about problems or ask questions (Gonzalez, 2016). Thus, students, especially those are shy and introverted can voice their opinions in a non-confrontational way, and build a deeper connection with the teacher compared to a regular classroom setting. 


\subsection{Collaborative Learning}

Another benefit of the dialogue journals is to provide a setting for the process of collaborative learning between students and their teacher (Bruner, 1988). In his study, Bode (1989) asserted that dialogue journal writing is liberating in the sense that it allows for the possibility of mutual conversations. This is the essence of teachers becoming liberating educators; teachers learn with and from their students. Both are empowered. This is in direct contrast to what Freire (1970) refers to as a "banking" method of education in which the teacher deposits knowledge into the heads of students. Instead of transferring knowledge statically as a fixed possession of the teacher, dialogue journals allow for the dynamic exchange of information. It is through dialogue journal writing that the educator can be personalized. This is very empowering in the sense that the essence of teaching is to meet each child at her or his point of need.

In addition, from a teacher's view, from keeping dialogue journals with her students, Reed (1988) stated that not only students, but also teachers learn from their students; then the teachers apply their knowledge for their instructions in the classroom along with the students' needs. Furthermore, Staton (1988) contended that dialogue journals provide teachers with opportunities in which they can find the appropriate "zone of proximal development" which identifies the difference between what each student is able to accomplish unaided and what the same student can accomplish with assistance.

Then, how do students progress through the learning process in journal writing? "Interactional scaffolding" is a good concept to explain how students are learning or exploring what they are writing in the process of keeping journals. Kreeft-Payton (1988b) explained the concept of interactional scaffolding as the way in which an adult, or more experienced peer, through social interaction with a learner, provides a process to solve a problem, achieve a goal, or carry out a task which would be beyond the learner's ability unassisted. In other words, through the process of writing and receiving feedback, students build on and use the teacher's actual thinking process to reach a goal or to solve a problem. This concept is based on the Vygotsky's (1978) theory that development of a child begins in social interaction with an adult as guide, until the child internalizes the kind of help received from the adult and guides herself or himself.

\subsection{Application to SEL}

Two major benefits are attributed to the use of the journals in schools. First, in terms of "building student-teacher rapport", dialogue journals can establish trust between a student and teacher, which encourages the student to express individual concerns to a responsive audience without fear. The sense of taking equal roles with a confidential nature between a student and teacher enhances the student's trust to the teacher. This aspect of dialogue journals possibly encourages the children's sense of "safe school" and belonging to the school environment. McGrath (1992) stated that students were able to interact with their teacher in the dialogue journals in a confidential manner, and the journal medium was to be a "safe place" in which to converse. The findings by Hail and colleagues (Hail et al., 2013) support the idea that dialogue journals enhance the positive relationship between teachers and students, which further demonstrates that dialogue journals create a safe-space for students. They recruited 52 fourth-grade students in the United States to implement dialogue journals in order to look at the type of content that the students would write about. In the student-teacher dialogue journals, the students discussed various topics that they would share with their peers, as well as personal opinions, discussions about different aspects of their lives, and problems they were facing at school and at home.

Second, in exercising "collaborative learning", both students and teachers are able to find what they can do for improving their life. By identifying "the zone of proximal development", the teacher may be able to give the students appropriate suggestions in accordance with each student's needs. Through the "interactional scaffolding" in the dialogue journals, students may be able to identify their problems, and learn effectively to cope with the problems from their teacher.

During the process of writing journals, both students and teachers are empowered. Students especially feel a sense of ownership in learning and more autonomous in managing their academic and interpersonal life.

\section{Educational Implications}

Instructing students to write a lot on their own, and having them understand that writing creatively and freely is an important skill, can be a difficult aspect for teachers to teach. When teachers assign their students a writing task, most students may write on subjects only to please their teachers and parents. Therefore, teaching students motivation to write can be a challenge that can be solved with the use of dialogue journals. Gambrell and colleagues (Gambrell, Hughes, Calvert, Malloy, \& Igo, 2011) conducted a study to examine the relationship between literacy motivation in 180 elementary school students and authentic literacy tasks. Authentic literacy 
tasks involved the exchange of thoughts and ideas about books they were assigned with their adult pen pals, in which teachers were acting as the responder to their students' letters. The authors found that through the use of pairing up a student with an adult pen pal, students' literacy motivation increased and were maintained. They also found that when students write freely to an adult for a task that does not involve receiving a grade, students are more likely to engage in the task more forcefully because they value having an adult with whom they can exchange letters.

Dialogue journals may also be an activity that enhances free and creative writing that allows students to explore their thoughts and emotions, and even perhaps, bolsters their imagination — not just in the playground — but also in the classroom. By allowing students to communicate and explore their emotions and thoughts through dialogue journals, Mahn and John-Steiner (2008) argue that students can thereby transform their experiences from something that is interpersonal to an intrapersonal one. By doing so, they become self-aware of their process of writing, which is important in the process of learning to write creatively and effectively. Creative writing also takes practice and diligent guidance, just like any other form of learning. Thus, implementing dialogue journals in classrooms can allow teachers to attend to each of their students' writing by helping them improve their handwriting skills, grammar, and spelling. Teachers can also use dialogue journals to help their students articulate their thoughts and feelings clearly and distinctly (Staton, 1980).

\subsection{Introverted Children}

Introverted children have a preference for an environment that is not too stimulating compared to extroverted children (Cain, 2012). Thus, being surrounded in a classroom setting where one is expected to continuously participate in discussions and present projects and thoughts in front of peers and the teacher can be a difficult situation for introverted children to be in. It can especially be challenging for teachers to assess academic and social development of these students because they are less outspoken than their extroverted counterparts. Dialogue journals may play a critical role in allowing teachers to see how introverted students are following with their school work, making friends and any problems that they may be perceiving, and to best help them develop socially, emotionally and academically. The nature of dialogue journals as mentioned above allows teachers to get to understand and know their students by building rapport with them, and thus it can become a means of providing support for the students (Mahn \& John-Steiner, 2008). Introverted children may therefore benefit from dialogue journals with their teachers as it builds a safe-space for them to communicate their emotions and thoughts about any topic they wish to write about. Through the interaction, teachers may be able to learn the strengths and weaknesses of their introverted students and find out their interests in order to gear individualized classroom instructions that will be in the best interest of them (Jones, 1991; Peyton \& Staton, 1993).

\subsection{Learning a Second Language}

For individuals writing or speaking in a second language, support from their teachers and peers is critical to facilitate confidence and to reduce the anxiety in using a second language. Dialogue journals create a safe environment for students to explore different forms of writing, and even allow students to take risks in writing by not putting focus on grades, but rather accepting that mistakes are normal and the importance in learning from them (Mahn \& John-Steiner, 2008). Reyes (1991) compared the effectiveness between dialogue journals and literature logs in 6th grade Hispanic bilingual students, and found that students were more likely to derive meaning from writing in a second language through dialogue journals than literature logs. The author suggests that positive findings, such as the development of creative ideas and meaning, were reported through the use of dialogue journals because unlike literature logs, dialogue journals allow the student to choose a topic of his or her choice, which then implements a friendly and open atmosphere for the student to write in. Writing and speaking in a second language may be an intimidating activity, especially for children. Teachers can become mindful of their students' experiences framed by different cultures, religions and ethnicity, and provide friendly and individualized support to them to allow them to become more confident in their writing and communication skills and in their self-concept (Mahn \& John-Steiner, 2008; Reyes, 1991).

\section{Conclusion}

This paper has examined the benefits of using dialogue journals for enhancing children's social and emotional development. From the "building student-teacher rapport" perspective, dialogue journals would develop mutuality and trust between a student and a teacher, which encourage the student to express individual feelings and concerns without fear at school. From the "collaborative learning" perspective, journal writing would let both the students and the teacher be aware of what they can do for improving their environment. In the progression of "collaborative learning", "interactional scaffolding", would help students optimize their autonomy through which the students can cope with their problems. In addition, opportunities of identifying "the zone of 
proximal development" of students can be promoted for the teacher. This process would, finally, lead to the safe school environment. Accordingly, dialogue journals could greatly help teachers enhance children's social-emotional development.

In applying the dialogue journals at schools, however, there are two important points that teachers need to acknowledge. First is the issue of time constraints. In the meantime, it may be a good idea for a teacher to start exchanging the journals with his or her students once a week instead of every day because it may be difficult for the teacher to read forty journals every day. Hail et al. (2013) found that student-student dialogue journaling was successful at encouraging students to effectively and productively communicate with their peers because they felt respected and supported. Furthermore, students reported that they wanted to continue dialogue journaling with their peers after the study was completed, and they wanted to write freely to their peers.

Second, unlike more standard instructional methods, the dialogue journals may not work for all teachers. The journals symbolize a communicative process that depends on the involvement of both student and teacher; and what makes them effective is the mind and language of an interested and committed teacher. The success of dialogue journals depends on the teacher's enthusiasm and motivation. Principals and supervisors who want to encourage their use should stress the voluntary nature of the process, letting teachers initiate the project in their own way, when they feel ready. Nonetheless, we believe that the dialogue journals would be a great device to promote effective children's SEL environments.

\section{References}

Ashdown, M. D., \& Bernard, E. M. (2012). Can explicit instruction in social and emotional learning skills benefit the social-emotional development, well-being, and academic achievement of young children? Early Childhood Education Journal, 39, 397-405. http://dx.doi.org/10.1007/s10643-011-0481-x

Bode, B. A. (1989). Dialogue journal writing. The Reading Teacher, 42, 568-571.

Brackett, M. A., Elbertson, N. A., \& Rivers, S. E. (2015). Applying theory to the development of approaches to SEL. In J. A. Durlak, C. E. Domitrovich, R. P. Weissberg, \& T. P. Gullotta (Eds.), Handbook of Social and Emotional Learning: Research and Practice (pp. 20-32). New York: The Guildford Press.

Bruner, J. S. (1988). Foreword. In J. Staton, R. W. Shuy, J. Kreeft-Peyton, \& L. Reed (Eds.), Dialogue journal communication: Classroom, linguistic, social, and cognitive views (pp. vii-viii). Norwood, NJ: Ablex Publishing Corporation.

Cain, S. (2012). Quiet: The Power of Introverts in a World that Can't Stop Talking. New York: Crown Publishing Group.

Casanave, C. P. (Ed.). (1993). Journal writing. Tokyo: SFC.

Christenson, S. L., \& Havsy, L. H. (2004). Family-school-peer relationships: Significance for social, emotional, and academic learning. In J. E. Zins, R. P. Weissberg, M. C. Wang, \& H. J. Walberg (Eds.), Building academic success on social and emotional learning: What does the research say? (pp. 59-75). New York: Teachers College Press.

Daniels, H., \& Daniels, E. (2013). The Best-Kept Teaching Secret: How Written Conversations Engage kids, Activate Learning, Grow Fluent Writers... K-12. Thousand Oaks, CA: Corwin Literacy.

Durlak, J. A., Domitrovich, C. E., Weissberg, R. P., \& Gullotta, T. P. (2015). Handbook of Social and Emotional Learning: Research and Practice. New York: The Guildford Press.

Durlak, J. A., Weissberg, R. P., Dymnicki, A. B., Taylor, R. D., \& Schellinger, K. B. (2011). The impact of enhancing students' social and emotional learning: A meta-analysis of school-based universal interventions. Child Development, 82, 405-432. http://dx.doi.org/10.1111/j.1467-8624.2010.01564.x

Eksi, Y. G. (2013). E-dialogue journal: Student teachers' perspectives on their school experience. Procedia-Social and Behavioural Sciences, 70, 1810-1819. http://dx.doi.org/10.1016/j.sbspro.2013.01.257

Elias, M. J., Leverett, L., Duffell, J. C., Humphrey, N., Stepney, C., \& Ferrito, J. (2015). Integrating SEL with related prevention and youth development approaches. In J. A. Durlak, C. E. Domitrovich, R. P. Weissberg, \& T. P. Gullotta (Eds.), Handbook of Social and Emotional Learning: Research and Practice (pp. 33-49). New York: The Guildford Press.

Farmer, T. W., Lines, M. M., \& Hamm, J. V. (2011). Revealing the invisible hand: The role of teachers in children's peer experiences. Journal of Applied Developmental Psychology, 32, 247-256. http://dx.doi.org/10.1016/j.appdev.2011.04.006 
Freire, P. (1970). Pedagogy of the oppressed (M. B. Ramos, Trans.). New York: The Seabury Press (Original work published 1968).

Fulwiler, T. (Ed.). (1987). Journal Book. Portsmouth, NH: Heineman Educational Books Inc.

Gambrell, B. L., Hughes, M. E., Calvert, L., Malloy, A. J., \& Igo, B. (2011). Authentic Reading, Writing, and Discussion: An exploratory study of a pen pal project. Chicago Journals, 112, 234-258. http://dx.doi.org/10.1086/661523

Gambrell, L. B. (1985). Dialogue journals: Reading-writing interaction. The Reading Teacher, 38, 512-515.

Gonzalez, J. (2016). Dialogue journals [Interview]. Retrieved from http://www.cultofpedagogy.com/episode-49/

Greenberg, M. T. et al. (2003). Enhancing school-based prevention and youth development through coordinated social, emotional, and academic-learning. American Psychologist, 58, 466-474. http://dx.doi.org/10.1037/0003-066X.58.6-7.466

Hail, C., George, S., \& Hail, J. (2013). Moving beyond journaling to dialogues in writing. Critical Questions in Education, 4, 42-51.

Hall, N., \& Duffy, R. (1987). Every child has a story to tell. Language Arts, 64, 523-531.

Hamre, K. B., \& Pianta, C. R. (2006). Student-teacher relationships. In G. G. Bear, \& K. M. Minke (Eds.), Children's needs III: Development and prevention (pp. 59-71). Washington, DC: National Association of School Psychologists.

Jaffe, P. G., Wolfe, D., Crooks, C., Hughes, R., \& Baker, L. L. (2004). The fourth R: Developing health relationships through school-based interventions. In P. G. Jaffe, L. L. Baker, \& A. J. Cunningham (Eds.), Children from domestic violence (pp. 200-218). New York: Guilford Press.

Jones, P. (1991). The various benefits of dialogue journals. In J. K. Peyton, \& J. Staton (Eds), Writing Our Lives: Reflections on Dialogue Journal Writing with Adults Learning English (pp. 102-128). New Jersey: Prentice Hall Regents.

Kreeft-Payton, J. (1988a). Mutual conversations: Written dialogue as basis for building student-teacher rapport. In J. Staton, R. W. Shuy, J. Kreeft-Peyton, \& L. Reed (Eds.), Dialogue journal communication: Classroom, linguistic, social, and cognitive views (pp. 183-201). Norwood, NJ: Ablex Publishing Corporation.

Kreeft-Payton, J. (1988b). Dialogue writing: Bridge from talk to essay. In J. Staton, R. W. Shuy, J. Kreeft-Peyton, \& L. Reed (Eds.), Dialogue journal communication: Classroom, linguistic, social, and cognitive views (pp. 88-106). Norwood, NJ: Ablex Publishing Corporation.

Kreeft-Peyton, J., \& Seyoum, M. (1989). The effect of teacher strategies on students' interactive writing: The case of dialogue journals. Research in the Teaching of English, 23, 310-334.

Mahn, H., \& John-Steiner, V. (2008). The gift of confidence: A Vygotskian view of Emotions. In G. Wells, \& G. Claxton (Eds.), Learning for Life in the 21st Century: Sociocultural Perspectives on the Future of Education (pp. 46-58). New Jersey: Blackwell Publishing Ltd.

McGrath, M. M. (1992). Writing before speaking: How the dialogue journal stimulates conversation (Unpublished master's thesis). Biola University, La Mirada, CA.

McWhirter, J. J., McWhirter, B. T., McWhirter, E. H., \& McWhirter, R. J. (2003). At-risk youth: A comprehensive response for counsellors, teachers, psychologists, and human services professionals (3rd ed.). Pacific Grove, CA: Brooks \& Cole.

Mlecki, C. K., \& Elliott, S. N. (2002). Children's social behaviours as predictors of academic achievement: A longitudinal analysis. School Psychology Quarterly, 17, 1-23. http://dx.doi.org/10.1521/scpq.17.1.1.19902

Payton, J. W., Wardlaw, D. M., Graczyk, P. A., Bloodworth, M. R., Tompsett, C. J., \& Weissberg, R. P. (2000). Social and emotional learning: A framework for promoting mental health and reducing risk behaviour in children and youth. Journal of School Health, 70, 179-185. http://dx.doi.org/10.1111/j.1746-1561.2000.tb06468.x

Peyton, J. K., \& Staton, J. (1993). Dialogue journals in the multilingual classroom: Building language fluency and writing skills through written interaction (pp. 32-36). New Jersey: Greenwood Publishing Group. 
Pianta, R. J., \& Hamre, B. K. (2009). Classroom process and positive youth development: Conceptualizing, measuring, improving the capacity of interactions between teachers and students. New Directions for Youth Development, 121, 33-46. http://dx.doi.org/10.1002/yd.295

Potts, M. (1981). Dialogue journals: A first step in helping troubled students. Today's Education, 57, 34-35.

Reed, L. (1988). Dialogue journals make my whole year flow: The teacher's perspective. In J. Staton, R. W. Shuy, J. Kreeft-Peyton, \& L. Reed (Eds.), Dialogue journal communication: Classroom, linguistic, social, and cognitive views (pp. 56-72). Norwood, NJ: Ablex Publishing Corporation.

Reyes, L. M. (1991). Approach to literacy using dialogue journals and literature logs with second language learners. Research in the Teaching of English, 25, 291-313.

Ryan, R. M., \& Powelson, C. L. (1991). Autonomy and relatedness as fundamental to motivation in education. Journal of Experimental Education, 60, 49-66. http://dx.doi.org/10.1080/00220973.1991.10806579

Schonert-Reichl, K. A., \& Hymel, S. (1996). Promoting social development and acceptance in the elementary classroom. In J. Andrews (Ed.), Teaching students with diverse needs: Elementary classrooms (pp. 152-200). Scarborough, ON: Nelson.

Skalicka, V., Stenseng, F., Belsky, J., \& Wichstrom, L. (2015). Reciprocal relations between student-teacher relationship and children's behavioural problems: Moderation by child-care group size. Child Development, 86, 1557-1570. http://dx.doi.org/10.1111/cdev.12400

Staton, J. (1980). Writing and counseling: Using a dialogue journal. Language Arts, 57, 514-518.

Staton, J. (1987). The power of responding in dialogue journals. In T. Fulwiler (Ed.), Journal Book (pp. 47-63). Portsmouth, NH: Heineman Educational Books Inc.

Staton, J. (1988). Discussing problems. In J. Staton, R. W. Shuy, J. Kreeft-Peyton, \& L. Reed (Eds.), Dialogue journal communication: Classroom, linguistic, social, and cognitive views (pp. 202-244). Norwood, NJ: Ablex Publishing Corporation.

Staton, J., Shuy, R. W., Kreeft-Peyton, J., \& Reed, L. (Eds.). (1988). Dialogue journal communication: Classroom, linguistic, social, and cognitive views. Norwood, NJ: Ablex Publishing Corporation.

Vygotsky, L. (1978). Mind in society: The development of higher psychological processes (M. Cole, V. John-Steiner, S. Scribner, \& E. Louberman, Eds. \& Trans.). Cambridge, MA: Harvard University Press.

Wall, M. (1981). Dialogue journals: A counselor responds. Today's Education, 57, 36-37.

Wentzel, K. R. (1993). Does being good make the grade? Social behaviour and academic competence in middle school. Journal of Educational Psychology, 85, 357-364. http://dx.doi.org/10.1037/0022-0663.85.2.357

Zins, J. E., Bloodworth, M. R., Weissberg, R. P., \& Walberg, H. J. (2004). The scientific base linking social and emotional learning to school success. In J. E. Zins, R. P. Weissberg, M. C. Wang, \& H. J. Walberg (Eds.), Building academic success on social and emotional learning: What does the research say (pp. 3-22). New York: Teachers College Press.

\section{Copyrights}

Copyright for this article is retained by the author(s), with first publication rights granted to the journal.

This is an open-access article distributed under the terms and conditions of the Creative Commons Attribution license (http://creativecommons.org/licenses/by/4.0/). 